\title{
W-SKARNS FROM RUBELITA, NORTHERN MINAS GERAIS STATE, BRAZIL: FLUIDS RELATED TO LITHOLOGICAL EVOLUTION
}

\section{FRANCISCO JAVIER RIOS ${ }^{1}$, KAZUO FUZIKAWA ${ }^{1}$, JOSÉ MARQUES CORREIA NEVES ${ }^{1}$ AND RAIMUNDO NETUNO NOBRE VILLAS ${ }^{2}$}

\begin{abstract}
In the southern Rubelita area, mid-Jequitinhonha Valley, scheelite mineralizations associated to calc-silicate rocks (with quartz, pyroxene, amphibole and grossular) and apatite bearing quartz veins occur. These rocks were intruded by pegmatitic granitoids and muscovitebiotite granites now cropping out in the area. Microthermometry and micro-Raman analyses of early (primary?) fluid inclusions in quartz, titanite and grossular from calc-silicate matrix and quartz veins indicate the presence of nitro-carbonic phases. They consist of variable proportions of $\mathrm{CH}_{\text {and }} \mathrm{N}_{2}\left(\mathrm{X}_{\mathrm{CH}}=0.35-1.0 ; \mathrm{X}_{12}=0.0-0.65\right)$. At a later stage, percolation of aquo-carbonic fluid in microfractures originated secondary fluid inclusions. This low salinity ffuid is $\mathrm{CO}_{2}$ dominated $\left(\mathrm{X}_{2}=0.95-1.0\right)$ with $\mathrm{N}_{2}$ and $\mathrm{CH}_{4}$ in trace amounts. These solutions have been studied in quartz veins of the calc-silicate rocks and presented $f \mathrm{O}_{2}$ between $10^{-36^{2}}$ and $10^{-34}$ bars, formed under 1500 bar pressure and temperatures between 200 and $300^{\circ} \mathrm{C}$. It is assumed that the $\mathrm{O}_{2}$ increase in the fluids is a consequence of muscovite-biotite-granitoid intrusion. Although direct fluid inclusions study on scheelite crystals have not been feasible, the tungstate precipitation from these late aquo-carbonic solutions was estimated, based on paragenetic relations. These fluids may have originated from granitoids bodies and may probably have reacted with the host schists leaching $\mathrm{Ca}$ and Fe from them.
\end{abstract}

Keywords: w-skarn, fluid inclusions, scheelite, Rubelita-Araçuaí, Minas Gerais-Brazil

INTRODUCTION This paper presents a comparative study of fluid systems related to $\mathrm{W}$-skarns associated to scheelite-bearing quartz veins and to host granitoids, both outcropping in the southern Rubelita area, located in the Araçuaí area, mid-Jequitinhonha Valley, Minas Gerais, Brazil (Fig.1).

Geology Regionally the oldest rocks are of Archaean age (kinzigitic-gneiss, and migmatite complexes) in which homophanous or locally oriented granitoids of Brasiliano age are intruded (PedrosaSoares 1984). During the Proterozoic, Salinas Formation (micaschists and quartzites) and Macaúbas Group were generated (Pedrosa-Soares 1984, Monteiro 1986). Later, in the Upper Proterozoic, the rocks of the Salinas Formation were intruded by sin-, tardi-, and post-tectonic granitoids $(\mathrm{Rb} / \mathrm{Sr}$ age $=525 \pm 30 \mathrm{Ma})$ which were divided into biotitemuscovite granite, muscovite-biotite granite, and pegmatoid granite (Monteiro et al. 1990, Pedrosa-Soares et al. 1997). They all fall in the granite-granodiorite domain with alkaline trend. Granitoids cutting the Salinas Formation in the western border of the area have post-tectonic character presenting a biotite-granite core and two mica granites or muscovite-garnet leucogranites at the boundaries (Correia-Neves et al.
1982, Pedrosa-Soares 1984, Correia-Neves et al. 1986, Monteiro 1986, Pedrosa-Soares et al. 1997). These granites originated the pegmatites of mid-Jequitinhonha Valley. They are hosted by these granitoids themselves or by the Salinas Formation schists and quartzites (Correia-Neves et al. 1986, 1987). During the Tertiary and Quaternary São Domingos Formation lacustrine siltstones were deposited (Pedrosa-Soares et al. 1987). Quartz schists with associated quartz veins and granitoid rocks of the muscovite-biotite granite type and pegmatoid granite are the lithologies outcropping in the southern Rubelita area.

SOUTHERN RUBELITA AREA Metamorphic rocks

Quartz, oligoclase (sericitized and epidotized), titanite, grossular, calcite, epidote and black and white mica are the main constituents of the schists (Salinas Formation). Layers dominated by gray-greenish garnet with boudinage were called "calc-silicates" by Pedrosa-Soares (1984) and Monteiro (1986). They consist of quartz and anorthite rich plagioclase (granoblastic matrix) followed by green amphibole, pyroxene, titanite, garnet, carbonates, pyrite, scheelite, and zircon (Monteiro 1990) and represent impure calcareous rocks. The

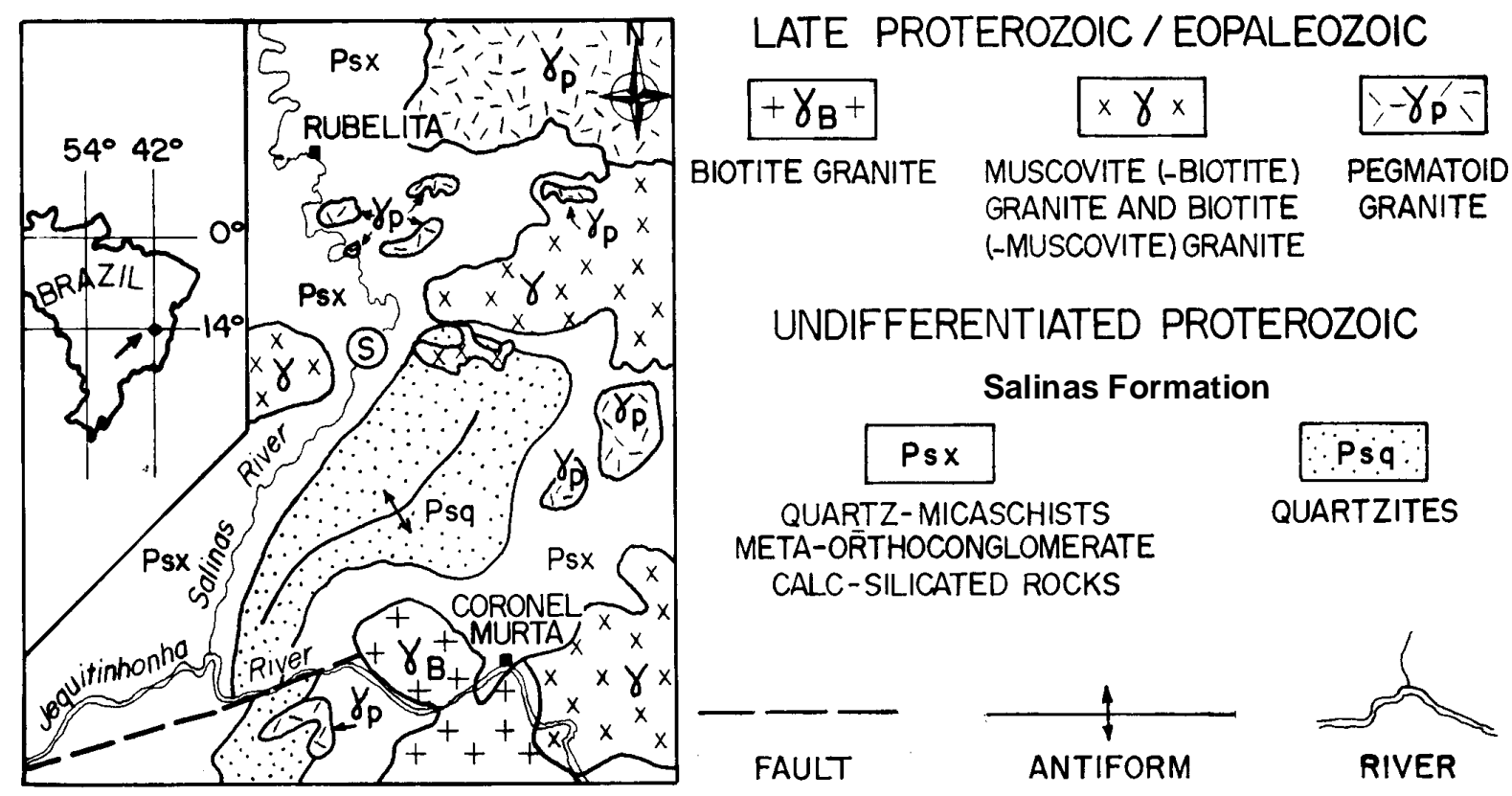

Figure 1 - Geologic map of the Rubelita Area, mid-Jequitinhonha Valley, Minas Gerais, Brazil (from Monteiro et al. 1990). (s): main scheelite studied mineralization.

1 - CDTN-CT2-LIF (CNEN), Belo Horizonte; C.P. 970, 30123-941 Belo Horizonte, Brazil, MG. E-mail: javier@urano.cdtn.br; kazuo@urano.cdtn.br, neves@urano.cdtn.br

2 - Departamento de Geologia, UFPa, C.P. 1611, 66075-900 Belém, PA. E-mail: netuno@ufpa.br 
amphibole is Fe-actinolite, whereas the pyroxene, which appears to be later than the amphibole, has a diopsidic composition with up to $22.5 \% \mathrm{CaO}$ and $11.5 \% \mathrm{MgO}$ content (salite, up to ferrosalite). The grossular generally enclosing quartz, amphibole, pyroxene, and titanite, has average composition of $20 \% \mathrm{CaO}, 21 \% \mathrm{Al}_{2} \mathrm{O}_{3}$, and $15 \%$ $\mathrm{FeO}$. The scheelite and the carbonates are interstitial and represent the latest crystallized phases. Grossular, muscovite, iron oxides, apatite, and rarely scheelite form the veins subordinate minerals. Near the granitoids, the scheelite frequently occurs at the central part of zoned boudins of quartz veins, as small grains intergrowth in the quartzfeldspathic matrix (Monteiro et al. 1990).

Granitoids They are of two main types: the pegmatoid granites and the muscovite-biotite bearing granites. The former ones are isotropic with quartz, K-feldspar, oligoclase, muscovite, and tourmaline. The muscovite-biotite bearing granites are quartz rich with subordinate biotite, muscovite, zircon, epidote, garnet, hematite, and magnetite composition (Monteiro 1986). Biotite encloses quartz, zircon, and iron oxides and is probably earlier than muscovite as it shows alteration to the latter. They are usually more altered than the pegmatoid granites.

FLUID INCLUSIONS STUDIES FI in quartz, garnet and apatite from calc-silicate rocks, in quartz veins, and in muscovite-biotite granites were studied. The results are summarized in Table 1.

Analytical methods Microthermometry was conducted on a Chaixmeca and a Fluid Inc cooling-heating stages at the Fluid Inclusion Laboratory in the "Centro de Desenvolvimento da Tecnologia Nuclear (CDTN)". Micro-Raman spectroscopy was performed at the Laboratory of Optics of the Department of Physics in the "Universidade Federal de Minas Gerais (UFMG)". Both laboratories are in the UFMG's Campus in Belo Horizonte, Minas Gerais.

Fluid Inclusion (FI) Types TYPE 1A They are early formed monophase carbonic or two phase aqueo-carbonic inclusions, with kidney to rounded shapes and 4-10 $\mu \mathrm{m}$ size, commonly confined to matrix quartz of the calc-silicate rocks. The carbonic phase of the aqueo-carbonic $\mathrm{FI}$ is $50 \%$ of inclusion volume and consists of $\mathrm{N}_{2}$ and $\mathrm{CH}_{4}$. $\mathrm{Th}_{\mathrm{CARB}}$ occurred between $-110^{\circ} \mathrm{C}$ and $-99^{\circ} \mathrm{C}$ invariably to the gas state. The high $\mathrm{Tm}_{\mathrm{CLAT}}\left(17\right.$ to $\left.21^{\circ} \mathrm{C}\right)$ is probably due to the high $\mathrm{CH}_{4}$ content in the carbonic phase, which is formed by $\mathrm{CH}_{4}\left(\mathrm{X}_{\mathrm{CH} 4}=\right.$ 0.35 to 1.0$)$ and $\mathrm{N}_{2}\left(\mathrm{X}_{\mathrm{N} 2}=0.0\right.$ to 0.65$) . \mathrm{CO}_{2}, \mathrm{H}_{2} \mathrm{~S}$, and $\mathrm{HS}^{-}$have not been detected. Tht of two phase FI took place between 350 to $450^{\circ} \mathrm{C}$ (more frequently $375^{\circ} \mathrm{C}$ ) with the expansion of the carbonic phase.

TYPE 1B They are early $(\mathrm{L}+\mathrm{V})$ FI in grossular and titanite from calcsilicate rock matrix. They are 8-10 $\mu \mathrm{m}$ in size and the gas phase (carbonic) reaches 10 to $30 \%$ of the inclusion volume. Mineral dark color prevented observations during cryometry. Only in a few inclusions, bubble recovery between -1.5 to $-1.0^{\circ} \mathrm{C}$ was noticed, which might be credited to the final ice melting $\left(\mathrm{Tm}_{\mathrm{ICE}}\right)$ or the clathrate dissociation. The vapor phase is formed by variable amounts of $\mathrm{CH}_{4}\left(\mathrm{X}_{\mathrm{CH} 4} 0.8\right.$ to 1.0$)$ and $\mathrm{N}_{2}\left(\mathrm{X}_{\mathrm{N} 2} 0.0\right.$ to 0.2$)$. Tht occurred between $240^{\mathrm{H}}$ and $340^{\circ} \mathrm{C}$, usually to the liquid phase, with concentration of values around $300^{\circ} \mathrm{C}$.

TYPE 1C These FI were studied in quartz of veins cross cutting the calc-silicate rocks. They are early, two-phase (bubble $<50 \%$ inclusion volume) or three-phase ( $\left.\mathrm{L}+\mathrm{V}+\mathrm{S}_{\text {(amorphous, isotropic) }}\right)$ inclusions. The $\mathrm{V}$ phase also consist of $\mathrm{CH}_{4}\left(\mathrm{X}_{\mathrm{CH} 4}=0.7\right.$ to 1.0$)$ and $\mathrm{N}_{2}\left(\mathrm{X}_{\mathrm{N} 2}=0.0\right.$ to 0.3 ). Preliminary measurements on the aqueous phase suggested the presence of $\mathrm{Ca}^{++}$(eutectic temperature $[\mathrm{Te}] \cong-49^{\circ} \mathrm{C}$ ) and showed low $\mathrm{Tm}_{\mathrm{ICE}}\left(-4.5\right.$ to $\left.-1.5^{\circ} \mathrm{C}\right)$. Although the clathrate formation had not been observed, the presence of $\mathrm{CH}_{4}$ and $\mathrm{N}_{2}$ indicate that the formation of their hydrates were highly possible. The actual salinity must, therefore, be higher than the $7 \mathrm{wt} \% \mathrm{NaCl}$ equivalent determined from the $\mathrm{Tm}_{\mathrm{ICE}}$ (Fuzikawa 1982). The Tht occurred always to the aqueous phase between 200 and $270^{\circ} \mathrm{C}$.

TYPE 2 They are present in vein quartz apatites. They are primary, two-phase (bubble always $<10 \%$ inclusion volume) FI, with tubular and rounded edges $\left(4-20 \mu \mathrm{m}\right.$ long). $\mathrm{Te}$ of $-48^{\circ} \mathrm{C}$ suggests the presence of $\mathrm{Ca}^{++}$in the fluid. $\mathrm{Tm}_{\mathrm{ICE}}$ between -3.5 and $-1.5^{\circ} \mathrm{C}$ indicate salinity of 3.4 to $6.6 \mathrm{wt} \% \mathrm{NaCl}$ equivalent. During micro-Raman analyses dark semi-circular solid phases were formed in the inclusions, probably due to the presence of carbonic phases. Heating caused homogenization to the liquid phase in a narrow range of 280 to $290^{\circ} \mathrm{C}$.

TYPE 3A They are aqueo-carbonic inclusions of secondary nature, generally found in vein quartz. The carbonic phase occupies 50 to $100 \%$ of the inclusion volume and shows $\mathrm{Tm}_{\mathrm{CO} 2}$ between -61.5 to $57.5^{\circ} \mathrm{C}$, revealing to be mainly composed of $\mathrm{CO}_{2}\left(\mathrm{X}_{\mathrm{CO} 2}=0.65\right.$ to 0.95$)$ mixed with $\mathrm{CH}_{4}\left(\mathrm{X}_{\mathrm{CH} 4}=0.05\right.$ to 0.3$)$. In some FI stable solid phases were present after the micro-Raman analyses. It might be a product of reaction of any undetected hydrocarbon present in inclusions. $\mathrm{Th}_{\mathrm{CO} 2}$ occurred between -5.0 and $14.5^{\circ} \mathrm{C}$, to the liquid state, indicating a density of 0.83 to $0.95 \mathrm{~g} / \mathrm{cm}^{3} \mathrm{CO}_{2}$ equivalent. Tm $\mathrm{Cl}_{\mathrm{T}}$ occurred between 8.5 and $9.0^{\circ} \mathrm{C}$ suggesting a salinity of $\sim 1 \mathrm{wt} \% \mathrm{NaCl}$ equivalent (Diamond 1992). Final Tht occurred between 250 and $290^{\circ} \mathrm{C}$ to the carbonic phase.

TYPE 3B They are secondary, one and two phase, elongated and kidney shaped FI in quartz from granitoids outcropping near the skarns. The aqueous phase is $<20 \%$ of the inclusion volume and one phase carbonic inclusions are common. $\mathrm{Tm}_{\mathrm{CO} 2}$ occurred between 58.2 and $-58.0^{\circ} \mathrm{C}$, and micro-Raman analyses indicated $\mathrm{X}_{\mathrm{CO} 2}=0.95$, $\mathrm{X}_{\mathrm{N} 2}=0.05$, and absence of methane. $\mathrm{Th}_{\mathrm{CO} 2}$, to the liquid state, occurred between +18.5 and $+22,5^{\circ} \mathrm{C}$ indicating a density of $0.83 \mathrm{~g} / \mathrm{cc} \mathrm{CO}$ equivalent. $\mathrm{Tm}_{\mathrm{Cl}}$ near $+8.0^{\circ} \mathrm{C}$ indicate salinity $<2 \mathrm{wt} \% \mathrm{NaCl}$ equivalent. In addition to the methane absence in the carbonic phase, the lower $\mathrm{CO}_{2}$ density differentiates the $3 \mathrm{~b}$ (granite) from $3 \mathrm{a}$ (vein) inclusions.

DISCUSSIONS AND CONCLUDING REMARKS Fluid evolution The earliest fluids studied (Type 1a) involved in the precipitation or recrystallization of matrix quartz in the calc-silicate rocks had variable, but significant, concentrations of $\mathrm{CH}_{4}$ and $\mathrm{N}_{2}$, (as well as the absence of $\mathrm{CO}_{2}$, suggesting strongly reducing conditions, Fig. 2) and a very subordinate aqueous phase. Sterner and Bodnar (1989) observed that changes in fluid composition during metamorphic processes are common. In this way, one can observe that fluids in grossular and titanite from the matrix present much lower $\mathrm{N}_{2}$ content. It is suggested, therefore, that the Type 1a FI with high $\mathrm{N}_{2}^{2}$ content may represent remainder fluids surviving quartz recrystallization process. The solutions precipitating the minerals of the matrix are (probably) of metamorphic origin because the large amounts of $\mathrm{CH}_{\text {f }}$ found are unusual in fluids of magmatic origin (Roedder 1984, Kamili et al. 1993, O’Reily et al. 1997). The presence of hydrocarbons may be related to graphite concentrations already identified in the Jequitinhonha area (Correia-Neves, person. comm.).

Table 1 - FI types and composition from Rubelita area (MG). Fill: degree of filling; Tm ${ }_{C O 2}: \mathrm{CO}_{2}$ melting temperature; Th ${ }_{C A R B(P H A S E)}$ :homogenization temperature

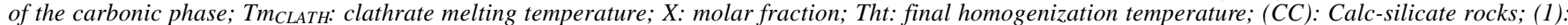
nucleation of solid phases (see text); $(G)$ : homogenization into the gas phase

\begin{tabular}{|c|c|c|c|c|c|c|c|c|c|c|}
\hline $\begin{array}{c}\text { FI } \\
\text { Type }\end{array}$ & Mineral & Fill & $\begin{array}{c}\mathrm{Tm}_{\mathrm{CO} 2} \\
\left({ }^{\circ} \mathrm{C}\right)\end{array}$ & $\begin{array}{c}\text { Th } \text { CARB } \\
\text { PHASE } \\
\left({ }^{\circ} \mathrm{C}\right) \\
\end{array}$ & $\begin{array}{c}\text { Tm } \\
\text { CLATH } \\
\left({ }^{\circ} \mathbf{C}\right) \\
\end{array}$ & $\mathbf{X}_{\mathrm{CH} 4}$ & $\mathbf{X}_{\mathrm{N} 2}$ & $\mathbf{X}_{\mathrm{CO} 2}$ & $\begin{array}{c}\text { Salinity } \\
\text { (wt\% NaCl } \\
\text { equiv.) }\end{array}$ & Tht $\left({ }^{\circ} \mathrm{C}\right)$ \\
\hline $1 \mathrm{a}$ & Quartz (CC) & 0.5 & & $\begin{array}{c}-110 /-99 \\
(\mathrm{G})\end{array}$ & $17 / 21$ & $0.35 / 1.0$ & $0.0 / 0.65$ & 0.0 & & $350 / 450$ \\
\hline $1 \mathrm{~b}$ & Garnet, Titanite (CC) & $0.7 / 0.9$ & & & & $0.8 / 1.0$ & $0.0 / 0.2$ & 0.0 & & $240 / 340$ \\
\hline $1 \mathrm{c}$ & Quartz (veins) & $>0.5$ & & & & $0.7 / 1.0$ & $0.0 / 0.3$ & 0.0 & $>7$ & $200 / 270$ \\
\hline 2 & Apatite (veins) & $>0.9$ & & & & $(1)$ & & & 3.4 to 6.6 & $280 / 290$ \\
\hline $3 a$ & Quartz (veins) & $0.0 / 0.5$ & $-57.5 /-61.5$ & $5.0 / 14.5$ & $8.5 / 9.0$ & $0.05 / 0.3$ & 0.0 & $0.65 / 0.95$ & 1 & $250 / 290$ \\
\hline $3 b$ & Quartz (veins/granite) & $>0.8$ & $-58.0 /-58.2$ & $18.5 / 22.5$ & 8.0 & 0.0 & 0.05 & 0.95 & $<2$ & \\
\hline
\end{tabular}




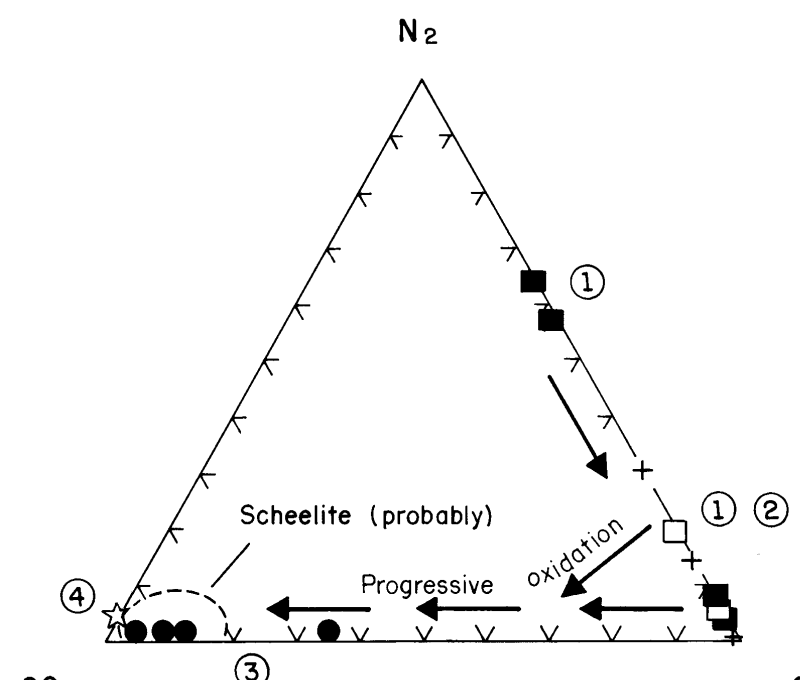

$\mathrm{CO}_{2}$

Figure $2-\mathrm{N}_{2}-\mathrm{CH}_{4}-\mathrm{CO}_{2}$ compositional diagram with fluid evolution path suggested for the Rubelita area. (1): calc-silicate matrix early fluids; (2): calcsilicate matrix and vein quartz early fluids; (3): quartz vein late fluids; (4):

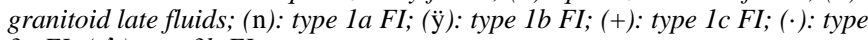
3 a FI; ( $\Delta r)$ type 3 b FI.

N.B.: Raman spectroscopy of Type 2 FI produced high luminescence dificulting the obtention of valuable data.

A silicification event that followed the fracturing episode of calcsilicate rocks originated an extensive web of millimetric and centimetric quartz veins. Solutions present during this process kept compositions similar to those described above with the predominance of $\mathrm{CH}_{4}$ (Fig. 2). Later change in the physico-chemical conditions led to a slight increase in salinity and addition of $\mathrm{CaCl}_{2}$ during apatite precipitation. Textural relationships indicate that scheelite was formed by substitution of calc-silicate minerals as a result of late alteration processes related to the granitoid emplacements (Monteiro 1986). Subsequently, the circulation of late low salinity $\mathrm{H}_{2} \mathrm{O}-\mathrm{CO}_{2}$ fluids probably caused the precipitation of muscovite. These fluids present in inclusions along micro-fractures contain high $\mathrm{CO}_{2}$ proportions ( $>65 \%)$, which increase progressively (in relation to earlier fluids) while the $\mathrm{CH}_{4}$ decreases until complete disappearance (Type $3 \mathrm{~b}$, Fig.2). This late stage aqueo-carbonic fluid circulated following the emplacement of granitoids. The density of the carbonic phases during type 3 fluid circulation indicated a minimum pressure of $\sim 1500$ bars. After granitoid emplacement, nevertheless, the pressure decreased to 1000/1200 bars.

Reducing and oxidizing stages Following quartz precipitation in the veins, physico-chemical conditions started changing in such a way that the oxygen concentration became relatively high, leading to a progressive transformation of methane into carbon dioxide and of a very reducing environment into a less reducing (or oxidizing) one due possibly to the granitoid intrusions. A possible methane oxidation reaction could have been such as $\mathrm{CH}_{4}+2 \mathrm{O}_{2} \Leftrightarrow$ $\mathrm{CO}_{2}+2 \mathrm{H}_{2} \mathrm{O}(1)$, which would have resulted in an increase of $\mathrm{CO}_{2}$ and $\mathrm{H}_{2} \mathrm{O}^{2}$ proportions.

The highly reducing early fluids from veins (Type 1c) did not contain $\mathrm{CO}_{2}$. The oxidation process started, therefore, during the circulation of fluid $3 \mathrm{a}$, although the possibility of it having started during apatite precipitation cannot be ruled out. The oxidizing conditions were established during the circulation of fluid $3 b$, after granitoid intrusion, as which coincides with the disappearance of methane.

Oxygen fugacity equilibrium conditions, for average temperatures of $300^{\circ} \mathrm{C}$ using reaction (1) and based on the Ohmoto \& Kerrich (1977) equation of state:

$\log \mathrm{K}=41997 / \mathrm{T}+0.7191 / \log \mathrm{T}-2.404$,

where $\mathrm{K}$ is the equilibrium constant, and $\mathrm{T}$ is the temperature in ${ }^{\circ} \mathrm{K}$, were calculated. The equilibrium constant is given by the ratio between the fugacity $(f)$ of products and reactants, or:
$\mathrm{K}=f_{\mathrm{CO} 2} \cdot f_{\mathrm{H} 2 \mathrm{O}}^{2} / f_{\mathrm{CH} 4} \cdot f_{\mathrm{O} 2}^{2}$

or in its logarithmic form:

$\log \mathrm{K}=\log f_{\mathrm{CO} 2}+2 \log f_{\mathrm{H} 2 \mathrm{O}}-\log f_{\mathrm{CH} 4}-2 \log f_{\mathrm{O} 2}$;

or in terms of molar fractions $(\mathrm{X})$ and fugacity coefficient $(\mathrm{g})$ :

$\log \mathrm{K}=\log \left(\mathrm{X}_{\mathrm{CO} 2 \mathrm{gCO} 2}\right)+2 \log \left(\mathrm{X}_{\mathrm{H} 2 \mathrm{OgH} 2 \mathrm{O}}\right)-\log \left(\mathrm{X}_{\mathrm{CH} 4 \mathrm{gCH} 4}\right)-2 \log f_{\mathrm{O} 2}$.

Using type 3 fluid molar fraction data and the gi data taken from Ryzhenko \& Volkov (1971), for pressures of 1.5 to $2.0 \mathrm{kbar}, f_{\mathrm{O}^{2}}$ values between $10^{-36}$ and $10^{-37}$ bar were calculated, which is very close to the $\mathrm{CO}_{2}-\mathrm{CH}_{4}(1 \mathrm{kbar})$ and $\mathrm{WO}_{3} / \mathrm{WO}_{2}$ buffer curves. This indicates that despite the dominance of $\mathrm{CO}_{2}$ in the carbonic phase of type 3 a fluids the oxygen fugacity stood relatively low, consistent with reducing conditions. The obtained $f_{\mathrm{O} 2}$ values are roughly coincident with the ones published in other $\mathrm{W}$ deposits (Fig. 3). The $f_{\mathrm{O} 2}$ values for Rubelita 1a, 1b, and 1c fluids must, certainly, have been much lower considering the higher $\mathrm{CH}_{4}$ content and the absence of $\mathrm{CO}_{2}$.

Mineralizing fluid Which fluid system (or regime) would have been responsible for the $\mathrm{W}$ carriage and the scheelite precipitation in the Rubelita area? The absence of FI in scheelite prevented direct determination of these fluids. The FI study in minerals from rocks associated to the mineralization allowed a general constraint of the characteristics of this fluid. It must have percolated the rocks after the precipitation of vein quartz and grossular and have been coeval with apatite, which, in turn, is contemporaneous with scheelite. So, this fluid could be similar to those trapped as secondary FI in vein quartz (and probably in the apatite) consisting of a low salinity (with $\mathrm{CaCl}_{2}$ ) aqueous solution with $\mathrm{CO}_{2}$ as the main component and $\mathrm{CH}_{4}$ in trace amounts in the carbonic phase. The temperature would be in the 250 $-300^{\circ} \mathrm{C}$ range with slightly reducing character as shown by $\mathrm{fO}_{2}$ value around $10^{-36}$ bar. These physico-chemical characteristics are coincident with the ones postulated in other scheelite deposits (Roedder 1984, Ramboz et al. 1985, Durisova et al. 1992, Salim 1996, Kilias \& Konnes

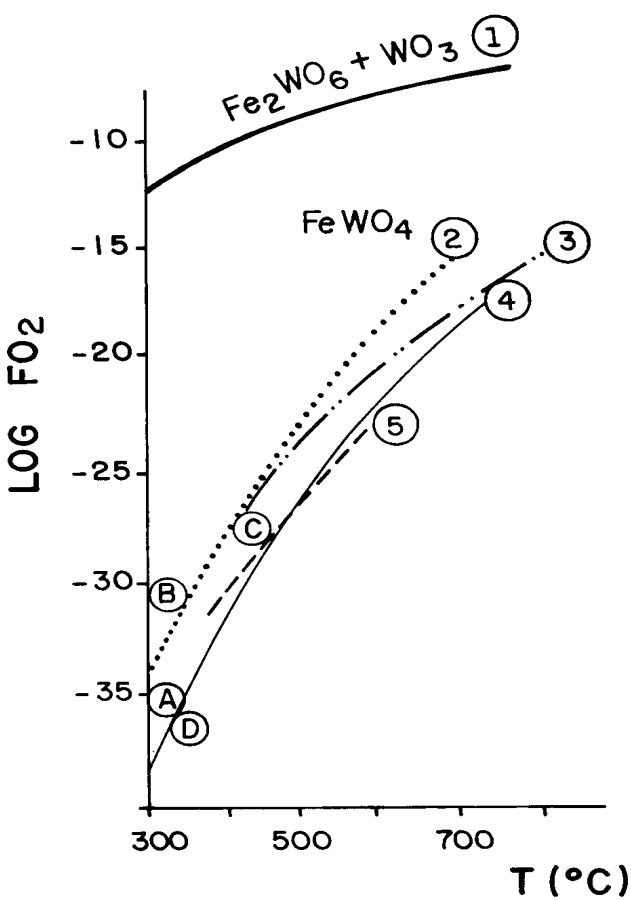

Figure 3 - Oxygen fugacity (log $f_{O 2}$ ) versus temperature diagram. Symbols: $(A)$ = Type 3 a aqueo-carbonic fluid from Rubelita; $(B)=$ Mineralizing aqueocarbonic fluid from Panasqueira W deposit, Portugal (Noronha et al. 1992); $(C)=$ Aqueo-carbonic $W$ mineralizing fluid of the Borne Granite-French Massif (Ramboz et al. 1985); (D) = Aqueo-carbonic mineralizing fluid from Pedra Preta W deposit, PA, Brazil (Rios 1995). Curves: (1) and (4) = Fe $\mathrm{WO}_{6}$

$+\mathrm{WO}_{3}$ and $\mathrm{WO}_{3} / \mathrm{WO}_{2}$, respectively, (Hsu 1976); (2) Buffer NNO for $2 \mathrm{kbar}$ (Ohmoto \& Kerrich 1977); (3) Representing the $\mathrm{CH}_{4}+2 \mathrm{O}_{2} \hat{\mathrm{U}} 2 \mathrm{H}_{2} \mathrm{O}+\mathrm{CO}_{2}$ reaction for 2 kbar (Smith et al. 1984); (5) Represents $X_{\mathrm{CH}_{4}}=0.1$ for $2 \mathrm{kbar}$ (Schwartz \& Surjono 1990). 


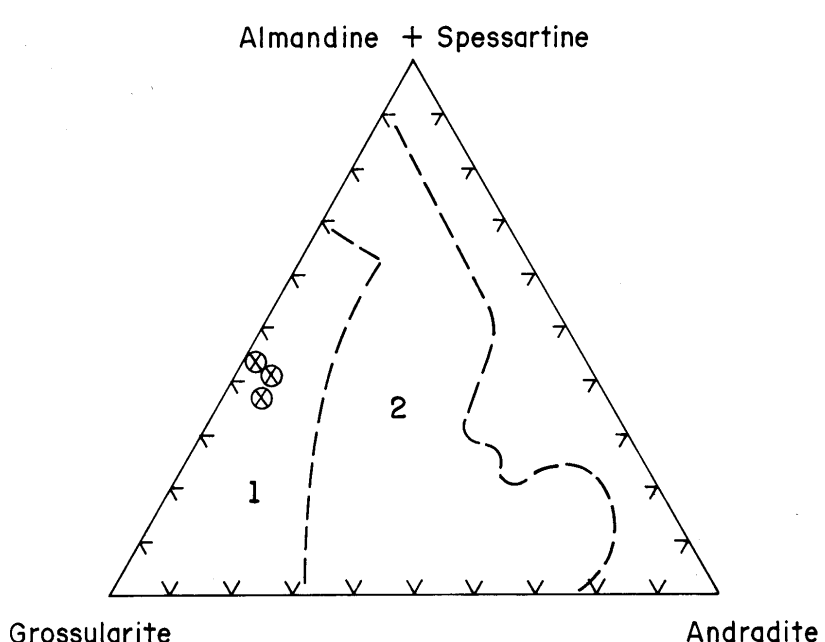

(1) Strongly reduced skarns

(2) Moderately reduced skarns

$\otimes$ Rubelita skarn

Figure 4 - Garnet of Rubelita skarn plotted in the subcalcic garnet diagram of Newberry (1983).

Thus, it is assumed that the Rubelita W minerals were precipitated from solutions having an important magmatic character or that they may have been derived directly from granitoids. This statement is based on: 1) W mineralizations hosted in metamorphic thermal aureole promoted by the granitoid bodies; 2) the average $\mathrm{W}$ content of metamorphic rocks in the Rubelita area is $<3 \mathrm{ppm}$, while in the nearby granitoids it may reach up to $8.2 \mathrm{ppm}$; geochemically, they have been considered slightly specialized and considered as the W source (Monteiro 1986, Monteiro et al. 1990); 3) scheelite and apatite are probably related to the aqueo-carbonic fluids compositionally identical to the late fluids investigated in quartz from the granites. Monteiro et al. (1990) argue that the $\mathrm{W}$ would have a magmatic source and the crustal granites, would have formed by melting of metamorphic rocks with anomalous $\mathrm{W}$ content. Aqueous fluids (with W) from the magma could have remobilized, by thermal convection, elements from the host rocks, forming the aqueo-carbonic fluids that transported $\mathrm{W}$ to the site of deposition. As the formation of scheelite needs high $\mathrm{Ca}^{++}$activity, it is probable that the tungstic acid $\left(\mathrm{H}_{2} \mathrm{WO}_{4}\right)$ reacted with calcic minerals from calc-silicate rocks leading to the scheelite precipitation. In addition, according to Marignac \& Cuney (1991) the presence of $\mathrm{N}_{2}$ could have had some importance in scheelite formation as solutions with $\mathrm{X}_{\mathrm{N} 2}=0.1$ would diminish the mineral solubility favoring its precipitation.

Considering the high $\mathrm{K}$-alkalic signature, the metaluminous up to peraluminous character, and the high $\mathrm{Sr}^{87} / \mathrm{Sr}^{86}$ initial ratio (0.713) of granites associated to the Salinas Formation schists Pedrosa-Soares $e t$ al. (1997) concluded that they could be included in the Ishihara's (1981) ilmenite series $\mathrm{S}$ type granites, which would suggest a reducing

\begin{tabular}{|c|c|c|}
\hline $\begin{array}{c}\text { Rubelita } \\
\text { (this paper) }\end{array}$ & $\begin{array}{c}\text { Oxidized W-Skarns } \\
\text { (Newberry \& Einaudi } \\
\text { 1981), (Meinert } \\
\text { 1992) }\end{array}$ & $\begin{array}{c}\text { Reduced W-Skarns } \\
\text { (Newberry \& Einaudi } \\
\text { 1981), (Newberry 1983), } \\
\text { (Meinert 1992) }\end{array}$ \\
\hline Small bodies & Small ore bodies & Large ore bodies \\
\hline Grossular (dominant) & Andradite & Spessartine-Almandine \\
\hline Diopside (Salite) & Diopside $\left(\mathrm{Hd}_{0-40}\right)$ & Hedenbergite \\
\hline $\begin{array}{l}\text { Mo poor Scheelite } \\
\text { (Monteiro et al 1990) }\end{array}$ & Mo poor Scheelite & Mo rich Scheelite \\
\hline Pyrite & Pyrite & $\begin{array}{l}\text { Pyrrhotite, Chalcopyrite, } \\
\text { Sphalerite, Arsenopyrite }\end{array}$ \\
\hline $\begin{array}{l}\text { Reducing stage: } \\
\mathrm{CH}_{4}, \mathrm{~N}_{2}\left(\text { no } \mathrm{CO}_{2}\right) \\
\text { Oxidizing stage: } \\
\mathrm{CO}_{2}>>\mathrm{CH}_{4}\end{array}$ & $\begin{array}{l}\mathrm{CO}_{2} \text { dominates over } \\
\mathrm{CH}_{4}\end{array}$ & $\mathrm{CH}_{4}$ dominates over $\mathrm{CO}_{2}$ \\
\hline $\begin{array}{l}\text { Grossular (Type 1b FI) } \\
\text { Tht }(\text { Max })=340^{\circ} \mathrm{C}\end{array}$ & \multicolumn{2}{|c|}{$\begin{array}{c}\text { Garnet (Prograde Mineral Assemb.) } \\
\text { Tht }=600-800^{\circ} \mathrm{C} \\
\text { Salinities }>52 \mathrm{wt} \% \mathrm{NaCl}\end{array}$} \\
\hline $\begin{array}{l}\text { Quartz (Type 1a FI) } \\
\text { Tht }=350-450^{\circ} \mathrm{C} \\
\text { Salinity: ? } \\
\text { Quartz (Type 3a FI) } \\
\text { Tht }=250-290^{\circ} \mathrm{C} \\
\text { Salinity }=1 \mathrm{wt} \% \mathrm{NaCl}\end{array}$ & \multicolumn{2}{|c|}{$\begin{array}{c}\text { Quartz (FI) } \\
\text { Th } 250-380^{\circ} \mathrm{C} \\
\text { Salinity }=2.5 \text { to } 28 \mathrm{wt} \% \mathrm{NaCl} \text { equiv. }\end{array}$} \\
\hline
\end{tabular}

Table 2 - Comparison between characteristics of Rubelita skarns and the reduced and oxidized $W$-skarn types.

character to the magma. This would be in agreement with the data from late FI in granite quartz, which are slightly reducing. It should be noted that W presents a strong affinity to S-type granite (Ishihara 1981).

Finally, the Rubelita skarns do not fit well in the oxidized and reduced W-skarns types postulated by Newberry \& Einaudi (1981) and Meinert (1992) (Table 2). The Rubelita skarns actually display characteristics from both types. The fluids of the garnet would represent reducing conditions (Fig.4). Nevertheless, the presence of pyroxene (salite) and low Mo bearing-scheelite (<6ppm, Monteiro 1986) is coincident with Meinert's (1992) oxidizing W-skarns (Table 2). Additionally, grossular and pyroxene at Rubelita are late in the calc-silicate mineral paragenesis, and may show intergrowths of both. In the Newberry \& Einaudi (1981) proposal, this pyroxene would be an indication of the beginning of less reducing stage, during which scheelite must have precipitated. Supporting this hypothesis, pyrite is absent in scheelite-bearing calc-silicate rocks ( Monteiro 1986).

Acknowledgements FJR acknowledges CNPq Post-Doctoral scholarship (Process 150.143/95-8) and FAPEMIG (grants 787/92 and 1046/95). To MSc. Rui Baptista Monteiro and the board of CPMTCIGC-UFMG for supplying mineralized samples from Rubelita area; to Dr. Essaïd Bilal for the access to the Geochemistry Laboratory - Ecole des Mines de Saint-Etienne (France) and microprobe analyses; to Drs. Maria Sylvia Souza Dantas and Marcos Assunção Pimenta for the access to the "Laboratório de Ótica - Dep. de Física", ICEX-UFMG, and to two anonymous referees of RBG for the critical review of the manuscript.

\section{References}

Correia Neves J.M., Monteiro R.L.B.P., Pedrosa Soares A.C. 1982. Granitóides da região de Coronel Murta, Minas Gerais, Brasil. I. Petrografia. In: SBG, Cong. LatinoAmericano de Geol, 5, Buenos Aires, Acta..2:133-146.

Correia Neves J.M., Pedrosa Soares A.C., Marciano V.R.P.R.O. 1986. A Provínci Pegmatítica Oriental do Brasil à luz dos conhecimentos atuais. Revista Brasileira de Geociências, 16(1):106-118.

Correia Neves J. M., Pedrosa Soares A. C., Marciano V. R. P. R. O., Monteiro R. L. B. P Fernandes M. L. S. 1987. Granitoids and pegmatites from the northern section of the Eastern Brazilian Pegmatite Province. In: SBG, ISGAM, I, Salvador. Excursion Guides, p. 125-140.

Diamond L.W. 1992. Stability of $\mathrm{CO}$ clathrate $+\mathrm{CO}_{2}$ liquid $+\mathrm{CO}_{2}$ vapour + aqueous $\mathrm{KCl}-$ $\mathrm{NaCl}$ solutions: Experimenta $\Gamma^{2}$ determination and application to salinity estimates of fluid inclusions. Geochimica et. Cosmochimica Acta, 56:273-280.

Durisova J., Sztacho P., Dubessy J .1992. A fluid inclusion study of Au-W stratiform mineralization at Orlík near Humpolec, Czechoslovakia. European Journal of Mineralogy, 4:965-976
Fuzikawa K. 1982. Fluid inclusions and oxygen isotope studies of the Nabarlek uranium deposit, NT Australia. The University of Adelaide, Doctoral Thesis, 226p.

Hsu L. C. 1976. The stability relations of the wolframite series. American Mineralogist 61:944-955.

Ishihara S. 1981. The granitoid series and mineralization. Economic Geology, 75:458-484 Kamilli R.J., Cole J.C., Elliot J.E., Criss R.E. 1993. Geology and genesis of the Baid Al Jimalah tungsten deposit, Kingdom of Saudi Arabia. Economic Geology, 88(7):17431767.

Kilias S.P. \& Konnerup-Madsen J. 1997. Fluid inclusion and stable isotope evidence for the genesis of quartz-scheelite veins, Metaggitsi area, central Chalkidiki peninsula, $\mathrm{N}$. Greece. Mineralium Depósita, 32:581-595.

Marignac C. \& Cuney M. 1991. What is the meaning of granite specialization for Sn, W deposit genesis? In: Pagel M. \& Leroy J. L. (eds); Source, transport and deposition of metals. A.Balkema, Brookfield, Rotterdam, p. 771-774

Meinert L.D. 1992. Skarns and skarn deposits. Geoscience Canada, 19:145-162. 
Monteiro R. L. B. P. 1986. As mineralizações de tungstênio no médio Vale do Jequitinhonha, NE de Minas Gerais. Instituto de Geociências, Universidade de Brasilia, Msc Thesis, 237p.

Monteiro R. L. B. P., Leonardos O H., Correia Neves J. M. 1990. An epigenetic origin for the new scheelite and wolframite occurrences in the middle Jequitinhonha Valley, Minas Gerais, Brazil. Revista Brasileira de. Geociências. 20:68-74.

Newberry R. J. 1982 Tungsten bearing skarns of the Sierra Nevada. I. The Pine Creek Mine, California. Economic Geology 77:823-844

Newberry R.J. 1983. The formation of subcalcic garnet in scheelite bearing skarns. Canadian Mineralogist. 21:529-544

Newberry R.J. \& Einaudi M.T. 1981. Tectonic and geochemical setting of tungsten skarn mineralization in the Cordillera, Arizona. Geol. Soc. Digest, 14:99-112.

Noronha F., Doria A., Dubessy J., Charoy B. 1992. Characterization and timming of the different types of fluids present in the barren and ore-veins of the W-Sn deposit of Panasqueira, Central Portugal. Mineralium Depósita, 27:72-79.

Ohmoto H. \& Kerrich D. M. 1977. Devolatilization equilibra in graphitic systems. America Journal of Science, 277:1013-1044.

O'Reily C., Gallagher V., Feely M. 1997. Fluid inclusion study of the Ballinglen W-Sn sulphide mineralization, SE Ireland. Mineralium Deposita, 32:569-580.

Pedrosa Soares A. C. 1984. Metamorfismo, granitogênese e mineralizações associadas na região de Coronel Murta, NE de Minas Gerais, Brasil. DEGEÓ, Universidade de Brasilia, Msc These.

Pedrosa Soares A.C., Monteiro R. L. B. P., Correia Neves J. M., Leonardos O. H., Fuzikawa K. 1987. Metasomatic evolution of granites, northeast Minas Gerais, Brazil. Revista Brasileira de. Geociencias, 17:512-518.

Pedrosa Soares A C. Wiedemann C. Fernandes M. L S. Faria L. F. Ferreira J. C. H. 1997 Geotectonic significance of the Neoproterozoic granitic magmatism in the Aracuai belt (SE Brazil): models and pertinent questions. In: Ferreira V.P \& Sial A.N.S. (ed)
Second International Symposium on Granites and Associated Mineralizations (ISGAM). Salvador, Bahia, Brazil, Extended Abstracts. p. 224-225.
Ramboz C., Schnapper D., Dubessy J. (1985) The P-V-T-X-fO evolution of $\mathrm{H}_{2} \mathrm{O}-\mathrm{CO}_{2}-\mathrm{CH}_{4}$ bearing fluid in a wolframite vein: reconstruction from fluid inclusions studies. Geochimica et. Cosmochimica. Acta, 49:.205-219.

Rios F.J. 1995. A jazida de wolframita de Pedra Preta, Granito Musa, Amazonia Oriental (PA): estudo dos fluidos mineralizantes e isótopos estáveis de oxigênio em veio hidrotermais. Centro de Geociências, Universidade Federal do Pará, Belém, Doctoral Thesis, 215p.

Ryzhenko B.N. \& Volkov S.A. 1971. The fugacity rule for the systems $\mathrm{CO}_{2}-\mathrm{H}_{2} \mathrm{O}, \mathrm{CO}_{2}-\mathrm{CH}_{4}$, $\mathrm{CO}-\mathrm{N}$ and $\mathrm{CO}-\mathrm{H}$. Geochemistry. International, 8(4):562-574 Roedder $\mathrm{E}_{2} \mathrm{~N}_{2}$ and. Fluid Inclusions. Reviews in Mineralogy V.12. Min. Soc. Amer, 641p. J. 1996. Mistura de fluidos e a deposição de scheelita nos skarns da Mina Bejuí,
Currais Novos (RN). In: SBG Congresso Brasileiro De Geologia, 39, Salvador. Anais.7:471-474.

Schwartz M.O. \& Surjono S. 1990. Greisenization and albitization at the Tikus tin-tungsten deposit, Belitung-Indonesia. Economic Geology, 85:691-713.

Smith T. J., Cloke P. L., Kesler S. E. 1984. Geochemistry of fluid inclusions from the Mc. Intyre Hollinger gold deposit, Timmins, Ontario, Canada. Economic Geology, 79:1265-1285.

Sterner S. M. \& Bodnar, R. J. 1989. Synthetic fluid inclusions-VII. Re-equilibration of fluid inclusions in quartz during laboratory-simulated metamorphic burial and uplift. Journal of. Metamorphic Geology, 7:243-260.
Contribution IGC-001

Received November 17, 1999 Accepted for publication May 10, 2000 